C. M. P. W. Mandigers - E. J. B. M. Mensink

A. Geurts van Kessel · D. C. van der Plas

C. Haanen - A. Hageme ÿer - T. de Witte

\title{
A long-lasting, complete hematologic and cytogenetic remission of chronic myelogenous leukemia after treatment with busulfan alone
}

Received: 27 October 1995 / Accepted: 27 February 1996

\begin{abstract}
A 44-year-old man suffering from cytogenetically and molecularly proven Philadelphia translocation-positive chronic myelogenous leukemia in chronic phase was treated with busulfan for 18 months and studied during a follow-up period of 13 years. Hematologically and cytogenetically, he attained a continuing complete remission, although at one point (9.5 years) at least, after attaining complete remission molecular analysis indicated the presence of minimal residual disease.
\end{abstract}

Key words Busulfan - Chronic myelogenous leukemia - Cytogenetic - Minimal residual disease • Polymerase chain reaction

\section{Introduction}

The clinical course of chronic myelogenous leukemia (CML) is characterized by a chronic phase lasting for an average of 3 years, followed by an accelerated phase and a blastic transformation. Survival after transformation is dismal and usually less than 3 months. Cytogenetic and molecular techniques have elucidated some pathophysiological mechanisms in CML, including the Philadelphia translocation $\left(\mathrm{Ph}^{\prime}\right)$. Generally, standard treatment of CML is not capable of eliminating the $\mathrm{Ph}^{\prime}$-positive clone and is therefore considered palliative, but not curative. Recently, therapies have been devised aiming at the eradication of the $\mathrm{Ph}^{\prime}$-positive

C. M. P. W. Mandigers · E. J. B. M. Mensink · C. Haanen ·

T. de Witte (西)

University Hospital Nijmegen, 544 Department of Hematology,

P. O. Box 9101, NL-6500 HB Nijmegen, The Netherlands

A. Geurts van Kessel

University Hospital Nijmegen, Department of

Anthropogenetica, The Netherlands

D. C. van der Plas · A. Hagemeÿer

Department of Cell Biology and Genetics, Erasmus University

Rotterdam, The Netherlands cell clone, a phenomenon designated $\mathrm{Ph}^{\prime}$ conversion. We present a patient with a very unusual hematologic, cytogenetic, and molecular course of CML after mild first-line oral therapy only.

\section{Case report}

In August 1982, a 44-year-old man, known to have nephrolithiasis, presented to the urologist with pain in his flank. He had no other complaints. Routine blood analysis revealed a leukocytosis. Physical examination was normal; the spleen was not palpable. A complete blood cell count revealed a hemoglobin of $8.8 \mathrm{mmol} / \mathrm{l}$, hematocrit of $0.451 / 1$, platelet count of $145 \times 10^{9} / 1$, white blood cell count of $74 \times 10^{9} / 1$ with $1 \%$ myeloblasts, $1 \%$ promyelocytes, $17 \%$ myelocytes, $9 \%$ metamyelocytes, $16 \%$ bands, $38 \%$ segmented neutrophils, $1 \%$ eosinophils, $3 \%$ basophils, $7 \%$ lymphocytes, and $7 \%$ monocytes. The value of lactate dehydrogenase was 486 units/l (normal <330 units/l). Further chemical examination of peripheral blood was normal. The leukocyte alkaline phosphatase score was unexpectedly elevated (1095/100 cells); it was absent at subsequent sampling. Slight hepatosplenomegaly was found on technetium scintigraphy.

Bone marrow morphology showed a predominance of myelopoiesis (myelopoiesis : erythropoiesis $=25: 1$ ) and $5 \%$ myeloblasts . Cytogenetic analysis of the bone marrow revealed the presence of the Philadelphia chromosome in three of three metaphases, and in one of these metaphases inversion of chromosome 7 was seen. The diagnosis of $\mathrm{Ph}^{\prime}$-positive chronic myelogenous leukemia in chronic phase was made. The Sokal index was 0.8 [12].

Before treatment, peripheral stem cells were collected by continuous-flow leukapheresis and cryopreserved to be used as stem cell rescue after intensive chemotherapy in case an accelerated or blastic phase should occur [3]. Cytogenetic analysis of these hematopoietic progenitor cells showed the Philadelphia chromosome in 20 of 20 metaphases, as well as an additional inversion of chromosome 7 in nine metaphases. Molecular analysis of these hematopoietic progenitor cells was performed 7.5 years later and revealed the presence of a hybrid breakpoint cluster regionAbelson (BCR-ABL) messenger ribonucleic acid (mRNA) of the b2a2 type. The method used has a sensitivity of detecting one malignant cell derived from CML cell line k562 in $10^{5}$ normal cells.

The patient was treated with busulfan orally in gradually decreasing doses for 18 months with a total amount of $686 \mathrm{mg}$. The peripheral blood cell count normalized after 6 months' treatment and remained normal during the follow-up period of 13 years after diagnosis. No aplastic phase occurred during or after busulfan 
Busulfan (mg/d orally)

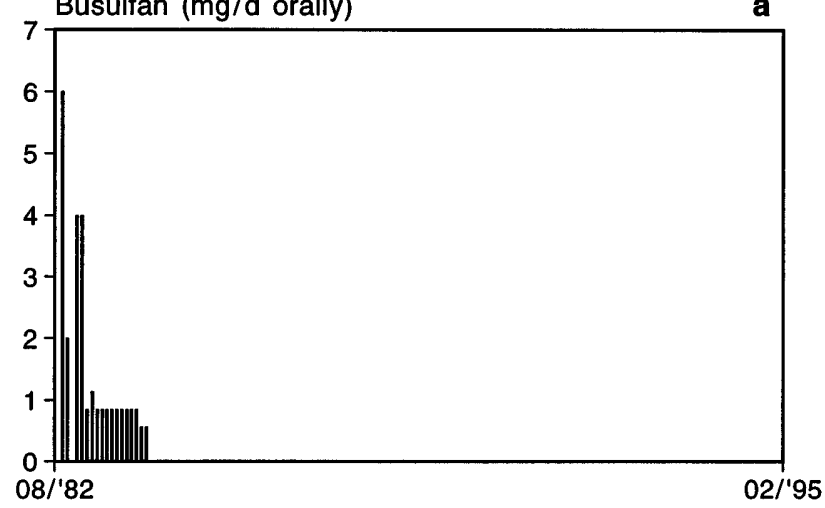

Leukocytes $(\times 10 \%)$

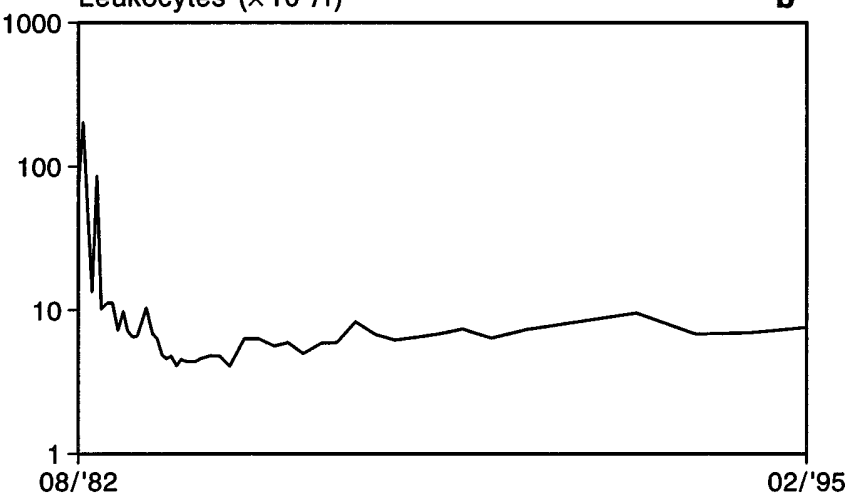

Platelets $\left(\times 10^{9} / 1\right)$

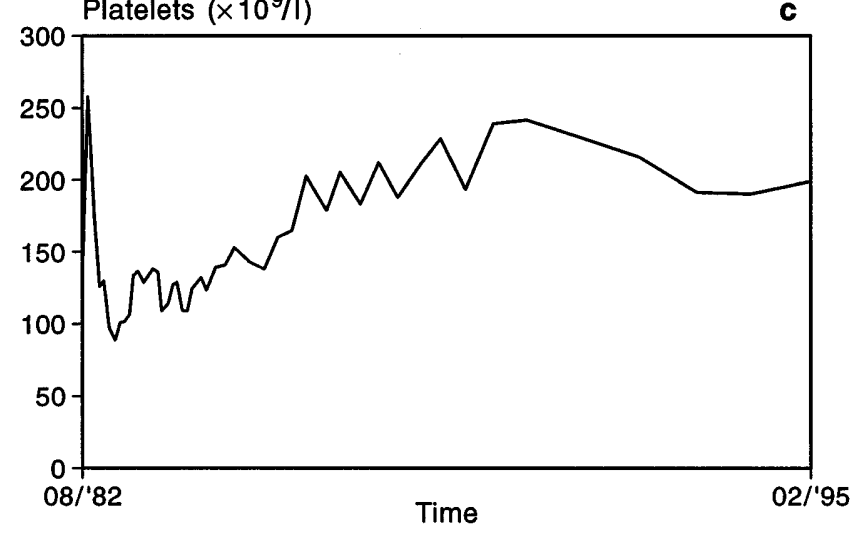

Fig. 1 Therapy (a) and values of leukocytes (b) and platelets (c) in peripheral blood during follow-up of patient

therapy (Fig. 1). Bone marrow morphology normalized 4.5 years after diagnosis and remained normal up to the most recent sampling, 11.5 years after diagnosis.

Sequential cytogenetic and molecular analysis of blood and bone marrow samples collected 4-13 years after diagnosis showed the almost complete conversion to a $\mathrm{Ph}^{\prime}$-negative status (Table 1). Molecular analysis was performed using the Southern blot technique in the beginning and later on reverse polymerase chain reaction, as described before [2]. The detection of BCR-ABL mRNA was only weakly positive in March 1992. Repeated testing gave the same weakly positive result. This indicates that the number of BCR-ABL mRNA molecules was then at the detection level of the test, suggesting a low expression of the hybrid BCRABL ongogene.

\section{Discussion}

Chronic myelogenous leukemia is a myeloproliferative disorder associated with the Philadelphia chromosome in more than $90 \%$ of patients. As a result of the Philadelphia translocation, the $\mathrm{ABL}$ oncogene is transferred from chromosome 9 (band 34) onto the BCR gene on chromosome 22 (band 11), where it encodes a chimeric BCR-ABL mRNA transcript resulting in a BCR-ABL fusion protein thought to be responsible for the leukemic transformation [4].

In the literature several therapeutic options for patients with CML are recommended [1, 6-9, 13]. The median survival of untreated patients is about 31 months. Symptoms of chronic-phase CML can usually be controlled with oral busulfan or hydroxyurea, which prolong the median survival to about 45 or 58 months, respectively [9]. After a remission of CML has been achieved with busulfan, the bone marrow usually remains $\mathrm{Ph}^{\prime}$ positive, although a few $\mathrm{Ph}^{\prime}$-negative remissions have been reported following busulfan-induced aplasia $[8,10]$. Intensive combination chemotherapy prolongs the median survival of chronic-phase CML patients to about 57 months and results in cytogenetic remission in up to a quarter of the patients. The median survival of patients with chronic-phase CML is lengthened to 72 months by treatment with interferon-alpha, which leads to (partial) cytogenetic remission in 30\% of cases. At present, the only curative option is allogeneic bone marrow transplantation, which is the treatment of choice especially in young patients with CML in chronic phase; it results in suppression of $\mathrm{Ph}^{\prime}$-positive cells in $100 \%$ and in a 3-year disease-free survival rate of about $63 \%$. A close correlation exists between disappearance of $\mathrm{Ph}^{\prime}$ and hematologic remission.

The long-lasting, practically complete $\mathrm{Ph}^{\prime}$ conversion of this patient is exceptional because it occurred after a mild oral chemotherapy regimen without an episode of bone marrow aplasia. The calculated Sokal index of 0.8 indicates an intermediate relative risk of dying, which is more than one may expect in this patient [12].

The Philadelphia translocation at diagnosis was cytogenetically and molecularly documented, in contrast to other reports $[5,11]$. Moreover, an additional aspecific cytogenetic abnormality, the inversion of chromosome 7, was documented in bone marrow and apheresis material at diagnosis. After treatment molecular studies showed a weakly positive signal of BCR-ABL mRNA at the detection level of the PCR technique on one occasion. Apparently, the growth potential of the leukemic clone has up to now been in equilibrium with that of the normal hematopoietic progenitor cells. An immunological suppression of the leukemic clone for at least 3 years cannot be excluded. Similar observations have been made only after allogeneic bone marrow transplantation [14]. 
Table 1 Sequential cytogenetic and molecular analyses of apheresis material, bone marrow, and peripheral blood of our patient ( $A M$ apheresis material, $B M$ bone marrow, $P B$ peripheral blood, $m B C R$ major breakpoint cluster region, $S B$ Southern blot)

\begin{tabular}{|c|c|c|c|c|c|}
\hline \multirow{2}{*}{$\begin{array}{l}\text { Date } \\
\text { (month/year) }\end{array}$} & \multirow[t]{2}{*}{ Material } & \multicolumn{2}{|c|}{ Cytogenetic analysis } & \multicolumn{2}{|c|}{ Molecular analysis } \\
\hline & & $\begin{array}{l}\text { Number of } \\
\text { metaphases }\end{array}$ & Karyotype & Technique & $\begin{array}{l}\text { Result } \\
\text { (breakpoint) }\end{array}$ \\
\hline \multirow[t]{4}{*}{ 09/1982 } & $\mathrm{BM}$ & 3 & $\begin{array}{l}46, x y, t(9 ; 22)[2] / \\
46, x y, t(9 ; 22), \operatorname{inv}(7)[1]\end{array}$ & & \\
\hline & $\mathrm{AM}$ & 20 & $\begin{array}{l}46, x y, t(9 ; 22)[11] / \\
46, x y, t(9 ; 22), \operatorname{inv}(7)[9]\end{array}$ & & \\
\hline & AM & & & SB & Positive (mBCR) \\
\hline & $\mathrm{AM}$ & & & RT-PCR & Positive (b2a2) \\
\hline $11 / 1986$ & $\mathrm{BM}$ & 6 & $46, x y$ & & \\
\hline 01/1987 & $\mathrm{BM}$ & 38 & $46, x y$ & & \\
\hline 09/1989 & $\mathrm{BM}$ & & & RT-PCR & Negative \\
\hline \multirow[t]{3}{*}{ 03/1992 } & $\mathrm{BM}$ & 21 & $46, x y$ & & \\
\hline & $\mathrm{BM}$ & & & RT-PCR & Weakly pos (b2a2) \\
\hline & PB & & & RT-PCR & Negative \\
\hline \multirow[t]{2}{*}{ 02/1994 } & $\mathrm{BM}$ & & & RT-PCR & Negative \\
\hline & $\mathrm{PB}$ & & & RT-PCR & Negative \\
\hline 02/1995 & $\mathrm{PB}$ & & & RT-PCR & Negative \\
\hline
\end{tabular}

Acknowledgements Part of this work was supported by the Dutch Cancer Foundation. We thank Ellen Linders for performing the BCR-ABL PCR assay.

\section{References}

1. Baccarani $\mathrm{M}$, The Italian cooperative study group on chronic myeloid leukemia (1994) Interferon alfa-2a as compared with conventional chemotherapy for the treatment of chronic myeloid leukemia. N Engl J Med 330:820-825

2. Bär BMAM, Schattenberg A, Mensink EJBM, Geurts Van Kessel A, Smetsers TFCM, Knops GHJN, Linders EHP, De Witte T (1993) Donor leukocyte infusions for chronic myeloid leukemia relapsed after allogeneic bone marrow transplantation. J Clin Oncol 11:513-519

3. De Witte T, Raymakers R, De Pauw B, Haanen C (1985) Repetitive cycles of cytoreductive therapy followed by stem cell autografting for nonlymphoblastic transformation of chronic granulocytic leukaemia. Scand J Haematol 3-5:421-426

4. Dreazen O, Canaani E, Gale RP (1988) Molecular biology of chronic myelogenous leukemia. Semin Hematolol 25:35-49

5. Fegan C, Morgan G, Whittaker JA (1989) Spontaneous remission in a patient with chronic myeloid leukaemia. Br J Haematol 72:594-595

6. Galton DAG (1969) Chemotherapy of chronic myelocytic leukemia. Semin Hematol 6:323-343

7. Goldman JM, Gale RP, Horowitz MM, Biggs JC, Champlin RE, Gluckman E, Hoffmann RG, Jacobsen SJ, Marmont AM, McGlave PB, Messner HA, Rimm AA, Rozman C, Speck B, Tura S, Weiner RS, Bortin MM (1988) Bone marrow transplantation for chronic myelogenous leukemia in chronic phase. Ann Intern Med 108:806-814

8. Griffin JD (1986) Management of chronic myelogenous leukemia. Semin Hematol 23 [Suppl 1]:20-26
9. Hehlmann R, Heimpel H, Hasford J, Kolb HJ, Pralle H, Hossfeld DK, Queisser W, Löffler H, Heinze B, Georgii A, V. Wussow P, Bartram C, Griesshammer M, Bergmann L, Essers U, Falge C, Hochhaus A, Queisser U, Sick C, Meyer P, Schmitz N, Verpoort K, Eimermacher H, Walther F, Westerhausen M, Kleeberg UR, Heilein A, Käbisch A, Barz C, Zimmermann R, Meuret G, Tichelli A, Berdel WE, Kanz L, Anger B, Tigges FJ, Schmid L, Brockhaus W, Zankovich R, Schläfer U, Weissenfels I, Mainzer K, Tobler A, Perker M, Hohnloser J, Messener D, Thiele J, Buhr T, Ansari H, and the German CML Study Group (1993) Randomized comparison of busulfan and hydroxyurea in chronic myelogenous leukemia: prolongation of survival by hydroxyurea. Blood 82:398-407

10. Najean Y, Miclea M, Tanzer J, Lessard M, Sigaux F (1991) Chronic myelocytic leukaemia with unusual (27 years) complete remission terminating in acute undifferentiated leukaemia: a clinical and karyotypic study. Leukemia 5:621623

11. Prischl FC, Haas OA, Lion T, Eyb R, Schwarzmeier JD (1989) Duration of first remission as an indicator of long-term survival in chronic myelogenous leukaemia. Br J Haematol $71: 337-342$

12. Sokal JE, Baccarani M, Russo D, Tura S (1988) Staging and prognosis in chronic myelogenous leukemia. Semin Hematol 25:49-61

13. Talpaz M, Kantarjian H, Kurzrock R, Trujillo JM, Gutterman JU (1991) Interferon-alpha produces sustained cytogenetic responses in chronic myelogenous leukemia Philadelphia chromosome-positive patients. Ann Intern Med 114:532-534

14. Van Rhee F, Lin F, Cross NCP, Reid CDL, Lakhani AKV, Szydlo RM, Goldman JM (1994) Detection of residual leukaemia more then 10 years after allogeneic bone marrow transplantation for chronic myelogenous leukaemia. Bone Marrow Transplant 14:609-612 